\title{
COMPARATIVE MEASUREMENT OF STREAM FLOW IN THE ETHIOPE RIVER FOR SMALL HYDROPOWER DEVELOPMENT
}

\author{
S. O. Otuagoma ${ }^{1}$, E. A. Ogujor ${ }^{2}$ and P. A. Kuale ${ }^{3}$ \\ 1,3 Electrical/EleCtronic EngineERING DePt, DELTA State University, OlEH CAMPUS. NIGERIA \\ ${ }^{2}$ Electrical/Electronic EngineERIng DEPT, University of Benin, Benin City. NIGERIA \\ E-mail Addresses: ${ }^{1}$ otuagoma@yahoo.com,2emma.ogujor@uniben.edu,3 paokuale@yahoo.com
}

\begin{abstract}
This study investigates comparative measurement of stream flow in the Ethiope River for small hydropower development Two methods - the Float and Current Meter or Bridge Broom Methods were investigated and values compared to determine best method for optimal power generation. Depth and width measurements were carried out by means of a canoe, ropes and tapes. Velocity measurement was carried out by means of a plastic bottle that is partially filled with sand and a stop clock. Ten different measurements were carried out at various locations along the river. The results show that the average volumetric flow rate from the Float Method was $13.8 \mathrm{~m}^{3} / \mathrm{s}$ while the volumetric flow rate from the Current Meter Method was $31.73 \mathrm{~m}^{3} / \mathrm{s}$. Thus, the Current Meter Method has high degree of accuracy than the Float Method. Hence the potential small hydropower generation inherent in the Ethiope River was estimated to be $1.323 \mathrm{MW}$ on a flow of $31.73 \mathrm{~m}^{3} / \mathrm{s}$ and a head of 5 meters. We can therefore conclude that the Ethiope River when fully utilised could generate electric power capable of satisfying the power need of the surrounding communities.
\end{abstract}

Keywords: small hydropower, electric power, volumetric flow, discharge, velocity

\section{INTRODUCTION}

The Ethiope River of Delta State, Nigeria, is a valuable water resource that can sustain water supply, irrigation, recreation and power generation as well as a diverse array of ecosystem types. The Ethiope River (Figure 1) takes its source from a spring at Umuaja and flows for over $100 \mathrm{~km}$ to empty into Benin River [1]. This river serves as the terminal point for storm run-off in the study area. The inhabitants of surrounding villages rely mainly on the river for their domestic water supply, fishing, sand mining and intervillage transportation.

The study area is situated in the north central part of Delta State between latitudes $5^{0} 40^{\prime} 6^{\prime \prime} \mathrm{N}$ and $6^{0} 00^{\prime} \mathrm{N}$ and longitudes $5^{0} 39^{\prime} 5^{\prime \prime} \mathrm{E}$ and $6^{0} 10^{\prime} 9^{\prime \prime} \mathrm{E}$ (Figure 2). It is located within the equatorial region having two climatic regimes: the wet season, which begins in about April and lasts till October and the dry season from November to March.

The Ethiope River has been studied by Ikomi [2] among others who described aspect of its hydrobiology and biotic populations. Adiotomre et al
[3] has also reported on the economic potentials of the Ethiope River. There appears to be no specific reported studies of the hydrology of the Ethiope River or indeed any of the rivers and creeks of the western Niger Delta apart from passing mention in general reports from the Niger Delta [4].

The reason for the dearth of hydrologic studies in Delta state and the western Niger Delta region in general is lack of long term data which is the result of the absence of environmental monitoring and data gathering systems. Indeed, the Ethiope River is one of the three rivers on which gauging stations were installed in Delta State. These gauging stations had broken down and unserviceable for years. Osula [5] reports that even these gauges were set up in 1980 under a hydrologic monitoring network initiative of the Benin Owena River Basin Authority (BORBA) with assistance from the World Meteorological Organisation (WMO).

The understanding of the River flow is crucial for the management of river in terms of quantity, water quality and overall water resources management. 


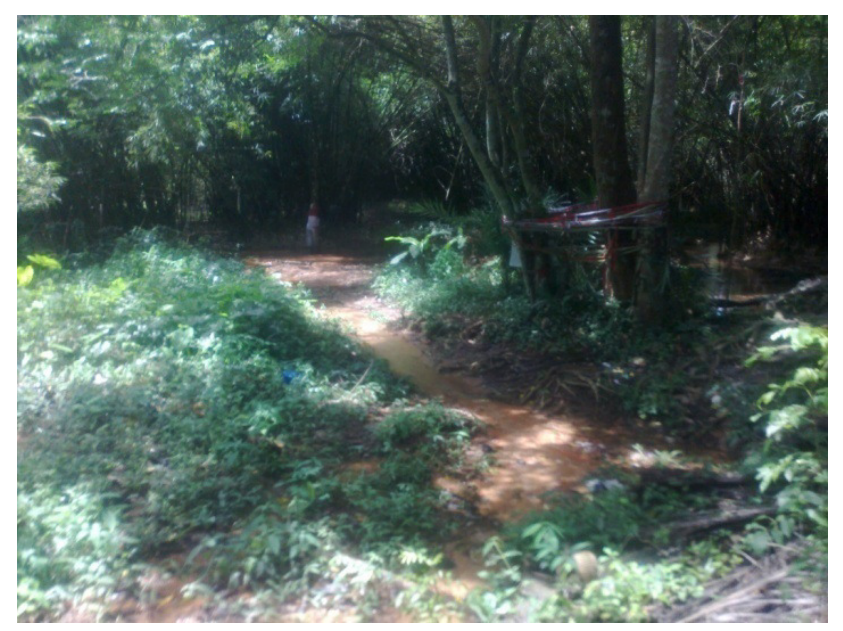

Figure 1: Ethiope River at the source at Umuaja.

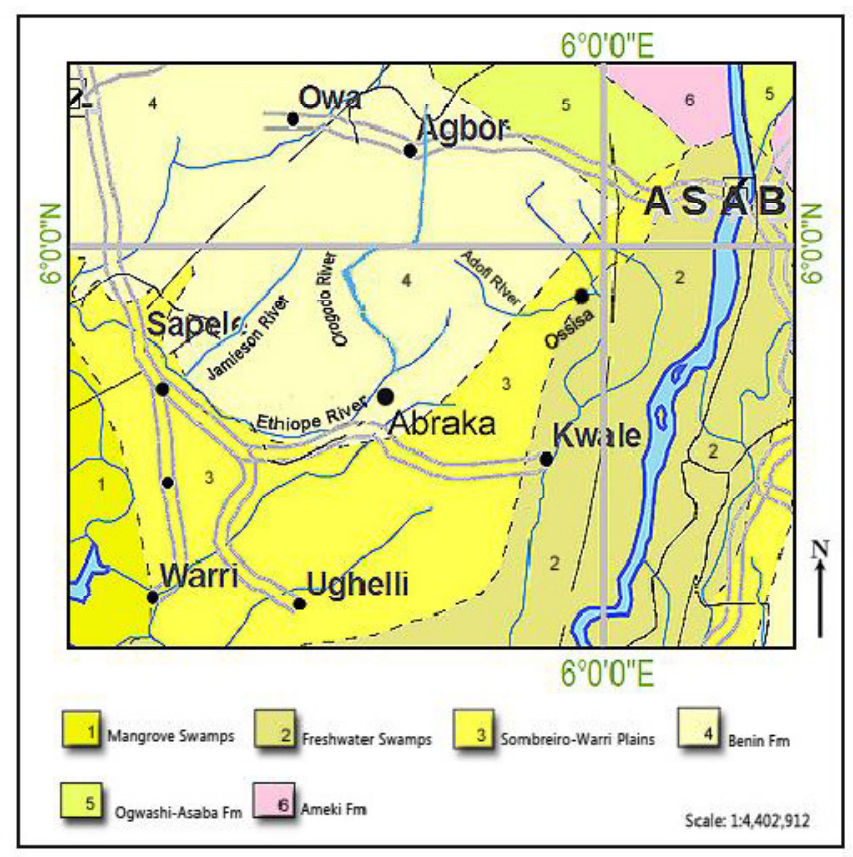

Figure 2. Geological Map of part of Western Niger Delta Showing the location of Ethiope River [4].

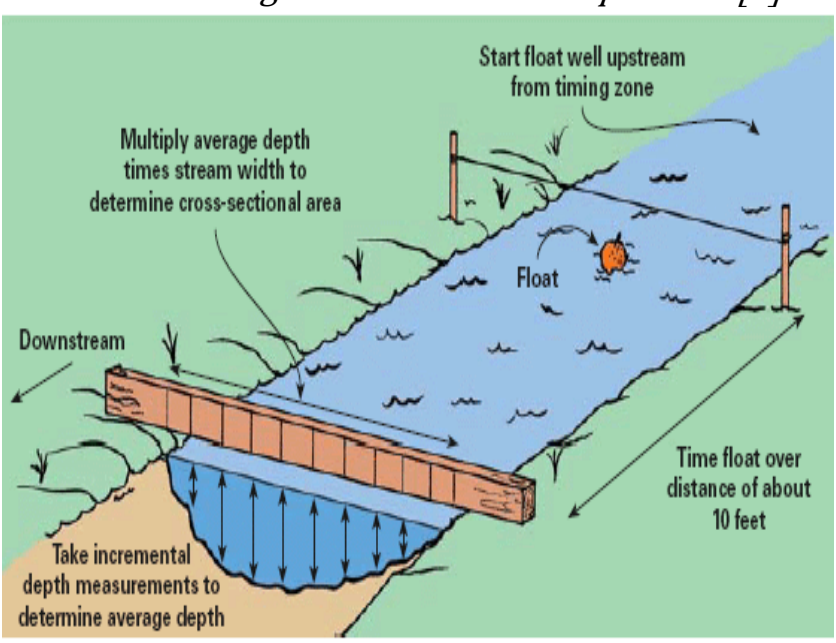

Figure 3: The float method of estimating flow.
River flow is thus critical in climate change issues related to the occurrence of floods, reliability of dry weather flows for water supply, irrigation, power generation, aquifer recharge and environmental management of aquatic ecosystem. Also, accurate measurement of volumetric flow is necessary for computing accurately samples used to characterize runoff and for the estimation of volumes [6].

This study therefore attempts to investigate various methods of flow measurement procedures to ascertain best method that will yield optimal power generation.

\section{MATERIALS AND METHODS}

In this study, hydrological measurements were carried out involving depth, width and flow velocity at various points along the Ethiope River course, to estimate the river discharge. Two methods were employed in this study to ascertain to some degree of accuracy the discharge of the river. The methods are: the Float and the Current Meter or Bridge Broom Methods.

\subsection{Float Method}

The float method is useful for large stream like Ethiope river since the lake-like structure at Umutu has section of more than $100 \mathrm{~m}$ long where the stream is fairly consistent in width and depth. A floating object was placed at the point in the river where the velocity is required. The time ' $\mathrm{t}$ ' it takes the float to cover a known distance ' $d$ ' as shown in Figure 3 was recorded. A floating object which was slightly submerged (plastic can partially filled with sand) was used. The surface velocity $\mathrm{V}$ of the water is given by the relation:

$V=d / t \quad(\mathrm{~m} / \mathrm{s})$

This method is not always accurate especially for large streams, since velocity varies from point to point with depth and width over the cross-section of the river.

\subsubsection{Depth and Width Measurements}

In this method, the discharge or flow rate is determined from the cross-sectional area and the mean velocity. The area of cross-section of the river is determined from the profile of the river bed obtained by lead lines. The lead line consists of a heavy weight attached to the lower end of a rope. The depth of water is measured when the lead touches the river bed. By means of a canoe, we were able to wade through the river holding the lead line vertically 
across the river and the water depth was measured at $10 \mathrm{~m}$ increment. Figure 4 shows how this method was employed.

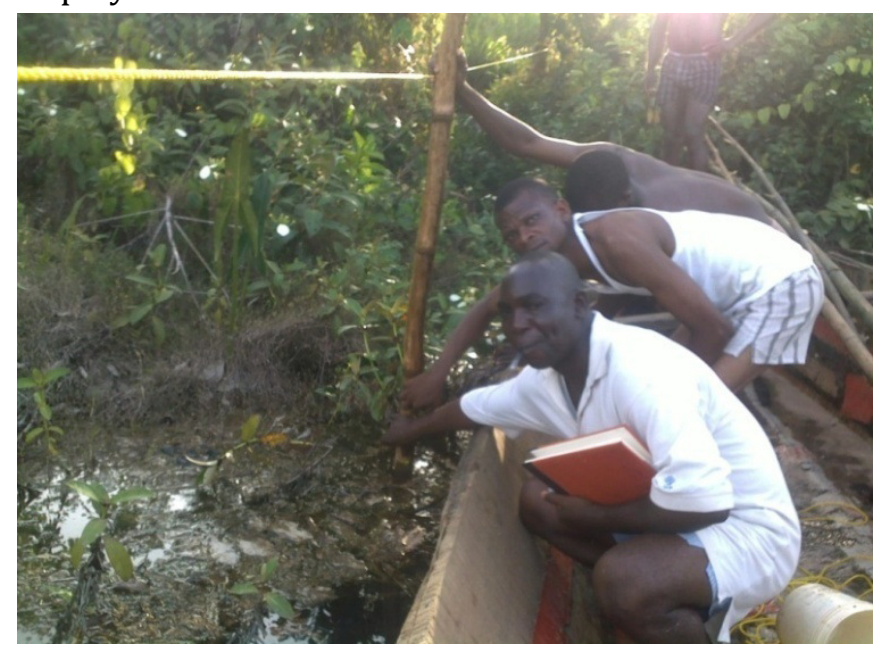

Figure 4: Measuring River Depth and Width at Ethiope River

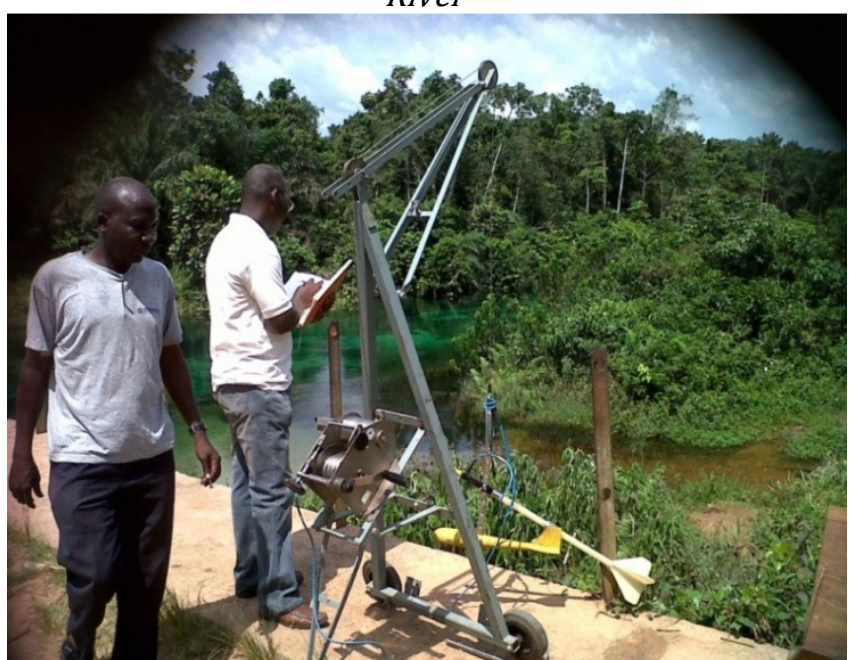

Figure 5: Measuring flow using the Current Meter method.

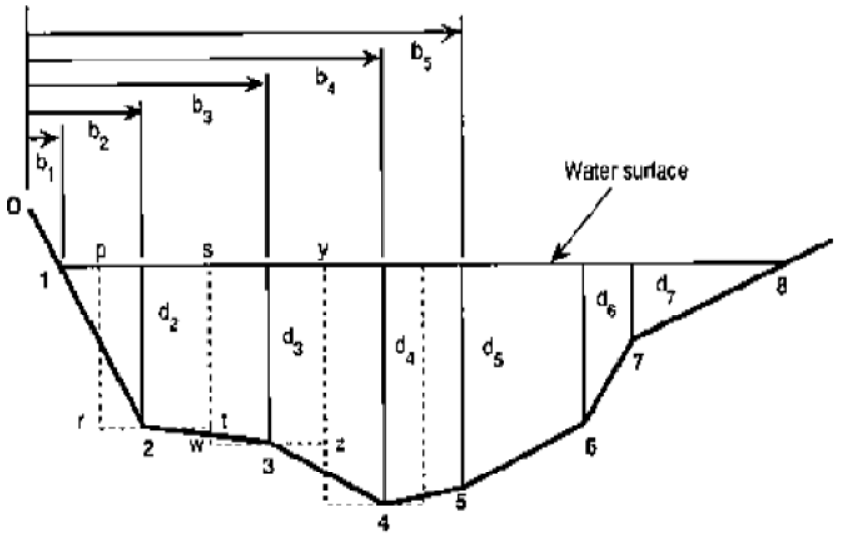

Figure 6: Cross section of the stream divided into vertical sections for measurement of discharge.

To help with the process, we stretched a rope upon which the increments of $10 \mathrm{~m}$ are marked across the river width of $81 \mathrm{~m}$. The river cross-section is divided into a suitable number of vertical segments. The total discharge in the river is computed as the sum of the discharges in various segments. The discharge in each segment is equal to the area of the segment multiplied by the mean velocity of flow [7]. The principle of all Area-Velocity methods is that flow, $Q$ equals the mean Velocity, $\mathrm{V}_{\text {mean }}$ times Cross-sectional area $\mathrm{A}$. That is;

$$
Q=V_{\text {mean }} \times A\left(\mathrm{~m}^{3} / \mathrm{s}\right)
$$

\subsection{Current Meter or Bridge Broom Method}

The Current Meter consists of a shaft with a propeller or revolving cups connected to the end. The propeller is free to rotate and the speed of the rotation is related to the river velocity. Simple mechanical counters record the number of revolutions of a propeller placed at a desired depth. By averaging readings taken evenly throughout the cross section, an average speed can be obtained which is more accurate than the float method [8].

In this study, the propeller type current meter was used as can be seen in Figure 5. In the bridge broom method, the current meter was lowered from the bridge at Abraka along Abraka/Benin road.

At this point, the river cross section was subdivided vertically into sections of $2 \mathrm{~m}$ intervals as shown in Figure 6 and velocity measurement was carried out at each of the sections. It has been determined empirically that for most channels the velocity at sixtenths of the total depth below the surface is a close approximation to the mean velocity at that vertical line.

However the average of the velocities at two-tenths and eight-tenths depth below the surface on the same vertical line provides a more accurate value of mean velocity at that vertical line as shown in Figure 7, [9].

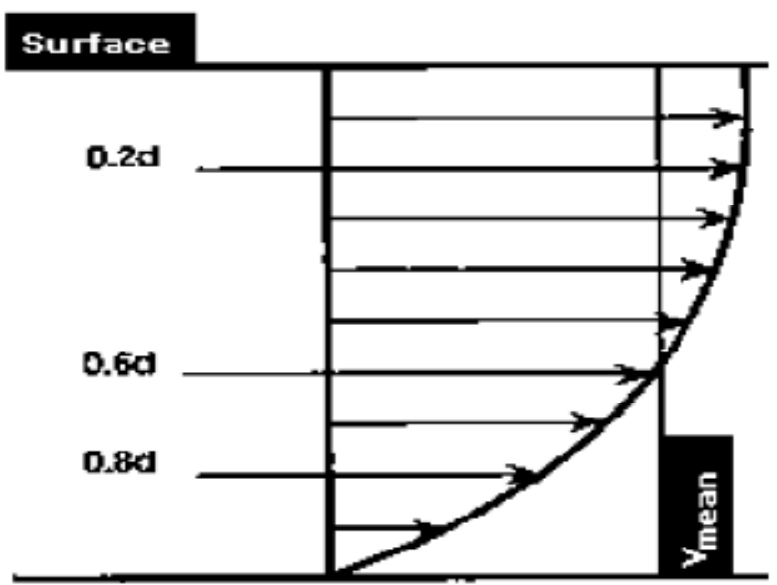

Figure 7: Typical river velocity profiles in the vertical plane 
The computation for discharge is based on the assumption that the average velocity measured at a vertical line is valid for a rectangle that extends half of the distance to the verticals on each side of it, as well as throughout the depth at the vertical. Thus, in Figure 6 , the mean velocity $V_{2}$ would be applied to a rectangle bounded by the dashed line p.r.s.t. The area of this rectangle is

$$
a_{2}=\frac{b_{3}-b_{1}}{2} \times d_{2}
$$

And the discharge through it will be:

$$
Q_{2}=a_{2} \times V_{2}
$$

Similarly, the velocity $\mathrm{V}_{3}$ applies to the rectangle $\mathrm{s}, \mathrm{w}$, $\mathrm{z}, \mathrm{y}$ and the discharge through it will be:

$$
Q_{3}=\frac{b_{4}-b_{2}}{2} \times d_{3} \times V_{3}
$$

The discharge across the whole cross-section will be:

$$
Q_{T}=Q_{1}+Q_{2}+Q_{3}+\ldots . .+Q_{n}
$$

Bridges are preferred at streaming stations because they usually allow easy access to the full length of the stream, and a water level indicator can be fastened to a bridge pier or abutment. Velocity measurements made from a boat are liable to yield inaccurate results because any horizontal or vertical movement of the boat will be identified as velocity by the current meter. In shallow streams, the water velocity close to the boat will be affected and this may distort the meter readings.

\section{RESULTS AND DISCUSSION}

\subsection{Flow Rate Measurements}

\subsubsection{Float Method}

The flow rate of the river was first measured using the Float method. In this method, the time it takes a buoyant object to float along a section of the river of known length and depth is measured. The crosssectional area in this particular section of the river is calculated using the measured width and average depth. Ten different measurements were made along the river at the centre of the lake of Umutu, at the collapsed bridge at Umutu and at the bridge on Abraka/Benin road, Abraka. The data collected from these measurements were recorded and presented in Tables $1-21$.

Area Evaluation:

Area (1):

Triangle $=1 / 2 b d=1 / 2 \times 1.4 \times 3.1=2.17 \mathrm{~m}^{2}$

Area (2): Trapezium:

$$
=1 / 2\left(d_{1}+d_{2}\right) b=1 / 2(1.4+1.94) 10=16.7 m^{2}
$$

Table 1: Depth and Width Measurement

\begin{tabular}{llll}
\hline S/N & Distance, d $(\mathrm{m})$ & Depth $(\mathrm{m})$ & Area $\left(\mathrm{m}^{2}\right)$ \\
\hline 1 & 3.1 & 1.4 & 2.17 \\
2 & 10 & 1.94 & 16.7 \\
3 & 10 & 2.70 & 23.2 \\
4 & 10 & 2.55 & 26.3 \\
5 & 10 & 3.50 & 30.3 \\
6 & 10 & 2.90 & 32 \\
7 & 10 & 2.60 & 27.5 \\
8 & 10 & 1.52 & 20.6 \\
9 & 10 & 0.43 & 7.6 \\
\hline
\end{tabular}

Area (3): Trapezium

$=1 / 2\left(d_{2}+d_{3}\right) b=1 / 2(1.94+2.7) \times 10=23.2 \mathrm{~m}^{2}$

Area (4): Trapezium:

$=1 / 2\left(d_{3}+d_{4}\right) b=1 / 2(27+2.55) 10=26.3 m^{2}$

Area (5) Trapezium $=1 / 2(2.55+3.5) 10=30.3 \mathrm{~m}^{2}$

Area (6) Trapezium $=\frac{(3.5+2.9)}{2} \times 10=32 \mathrm{~m}^{2}$

Area (7) Trapezium $=\frac{2.9+2.6}{2} \times 10=27.5 \mathrm{~m}^{2}$

Area (8) Trapezium $=\frac{2.6+1.52}{2} \times 10=20.6 \mathrm{~m}^{2}$

Area (9) Triangle $=1 / 2 b d=1 / 2 \times 10 \times 1.52=7.6 \mathrm{~m}^{2}$

The corresponding cross-sectional area of the river is:

$2.17+16.7+23.2+26.3+30.3+32+27.5+20.6$ $+7.6=186.37 \mathrm{~m}^{2}$

Table 2: Measurement (I) Velocity Measurements

\begin{tabular}{lll}
\hline Time $(\mathrm{s})$ & Distance $(\mathrm{m})$ & Velocity $(\mathrm{m} / \mathrm{s})$ \\
\hline 180 & 13.2 & 0.073 \\
192 & 13.2 & 0.069 \\
174 & 10.2 & 0.076 \\
\hline
\end{tabular}

Measurement (I) Average Volumetric Flow Rate: $\mathrm{Q}=\mathrm{V}_{\mathrm{cw}}$ $\times \mathrm{A}=0.073 \times 186.37=13.61 \mathrm{~m}^{3} / \mathrm{s}$

Table 3: Measurement 2, Depth and Width Measurement at collapsed bridge.

\begin{tabular}{llll}
\multicolumn{3}{c}{ at collapsed bridge. } \\
\hline S/N & Distance $(\mathrm{m})$ & Depth $(\mathrm{m})$ & Area $\left(\mathrm{m}^{2}\right)$ \\
\hline 1 & 2.5 & 0.2 & 0.25 \\
2 & 3.0 & 0.9 & 1.65 \\
3 & 3.0 & 1.7 & 3.90 \\
4 & 3.0 & 1.6 & 4.95 \\
5 & 3.0 & 1.0 & 3.90 \\
6 & 3.0 & 0.3 & 1.95 \\
7 & 2.6 & 0.1 & 0.52 \\
\hline Total Area & & & 17.12 \\
\hline
\end{tabular}


Table 4: Measurement 2. Velocity Measurement

\begin{tabular}{|c|c|c|c|}
\hline $\mathrm{S} / \mathrm{N}$ & Distance (m) & Time (s) & $\begin{array}{l}\text { Velocity } \\
(\mathrm{m} / \mathrm{s})\end{array}$ \\
\hline 1 & 3.0 & 4.71 & 0.637 \\
\hline 2 & 4.0 & 6.50 & 0.615 \\
\hline 3 & 5.0 & 12.06 & 0.415 \\
\hline 4 & 7.0 & 14.49 & 0.483 \\
\hline \multicolumn{3}{|c|}{ Average Velocity } & 0.538 \\
\hline \multicolumn{4}{|c|}{$\begin{array}{l}\text { Thus, the Measurement } 2 \text { Average Volumetric Flow Rate } \\
Q=V_{2} A_{2}=17.12 \times 0.538=9.21 \mathrm{~m}^{3} / \mathrm{s}\end{array}$} \\
\hline \multicolumn{4}{|c|}{ Table 5: Measurement 3. Depth and Width Measurement. } \\
\hline $\mathrm{S} / \mathrm{N}$ & Distance $(\mathrm{m})$ & Depth (m) & Area $\left(\mathrm{m}^{2}\right)$ \\
\hline 1 & 2 & 0.8 & 0.8 \\
\hline 2 & 3 & 1.2 & 3.0 \\
\hline 3 & 3 & 1.6 & 4.2 \\
\hline 4 & 3 & 1.9 & 5.3 \\
\hline 5 & 3 & 1.6 & 5.3 \\
\hline 6 & 3 & 1.3 & 4.4 \\
\hline 7 & 2 & 1.3 & 1.3 \\
\hline \multicolumn{3}{|c|}{ Total Area } & 24.3 \\
\hline
\end{tabular}

Table 6: Measurement 3. Velocity Measurement

\begin{tabular}{|c|c|c|c|}
\hline S/N & Distance (m) & Time (T) & $\begin{array}{l}\text { Velocity } \\
(\mathrm{m} / \mathrm{s})\end{array}$ \\
\hline 1 & 4 & 2.3 & 1.70 \\
\hline 2 & 12 & 6.0 & 2.0 \\
\hline 3 & 16 & 8.6 & 1.9 \\
\hline 4 & 18 & 12 & 1.5 \\
\hline \multicolumn{3}{|c|}{ Average Velocity } & 1.8 \\
\hline \multicolumn{4}{|c|}{$\begin{array}{l}\text { The average Volumetric Flow Rate: } \mathrm{Q}=\mathrm{VA}=1.8 \times 24.3= \\
43.0 \mathrm{~m}^{3} / \mathrm{s}\end{array}$} \\
\hline \multirow{2}{*}{\multicolumn{4}{|c|}{$\begin{array}{l}\text { Table 7: Measurement 4. Depth and Width Measurement } \\
\text { at the Lake (Umutu). }\end{array}$}} \\
\hline & & & \\
\hline 1 & 3.1 & 1.16 & 1.8 \\
\hline 2 & 10 & 2.04 & 16.0 \\
\hline 3 & 10 & 2.5 & 22.2 \\
\hline 4 & 10 & 2.4 & 24.5 \\
\hline 5 & 10 & 3.4 & 29.0 \\
\hline 6 & 10 & 2.9 & 31.5 \\
\hline 7 & 10 & 2.53 & 27.15 \\
\hline 8 & 10 & 1.5 & 20.15 \\
\hline 9 & 10 & 1.3 & 7.5 \\
\hline \multicolumn{3}{|c|}{ Total Area } & $179.8 \mathrm{~m}^{2}$ \\
\hline
\end{tabular}

Table 8: Measurement 4. Velocity Measurement.

\begin{tabular}{llll}
\hline $\mathrm{S} / \mathrm{N}$ & Distance $(\mathrm{m})$ & Depth $(\mathrm{m})$ & Area $\left(\mathrm{m}^{2}\right)$ \\
\hline 1 & 10 & 180 & 0.056 \\
2 & 10 & 186 & 0.054 \\
3 & 10 & 240 & 0.042 \\
\hline \multicolumn{4}{l}{ Average Velocity } \\
\multicolumn{4}{l}{ The Volumetric Flow Rate for the Measurement 4 is: $\mathrm{Q}=$} \\
$\mathrm{VA}=179.8 \times 0.046=8.27 \mathrm{~m}^{3} / \mathrm{s}$
\end{tabular}

$\mathrm{VA}=179.8 \times 0.046=8.27 \mathrm{~m}^{3} / \mathrm{s}$
Table 9: Measurement 5: Depth and Width measurement

\begin{tabular}{llll}
\hline S/N & $\begin{array}{l}\text { Distance } \\
(\mathrm{m})\end{array}$ & $\begin{array}{l}\text { Depth } \\
(\mathrm{m})\end{array}$ & Area $\left(\mathrm{m}^{2}\right)$ \\
\hline 1 & 3.1 & 1.3 & 2.015 \\
2 & 10 & 2.05 & 16.75 \\
3 & 10 & 2.67 & 23.60 \\
4 & 10 & 3.04 & 28.55 \\
5 & 10 & 3.22 & 31.30 \\
6 & 10 & 3.34 & 32.80 \\
7 & 10 & 3.05 & 31.95 \\
8 & 10 & 2.63 & 28.40 \\
9 & 10 & 1.6 & 8.0 \\
\hline Total Area & & & $203.37 \mathrm{~m}^{2}$ \\
\hline
\end{tabular}

Table 10: Measurement 5, Velocity Measurement

\begin{tabular}{llll}
\hline S/N & Distance & Time & Velocity \\
\hline 1 & 10 & 180 & 0.056 \\
2 & 10 & 182 & 0.055 \\
3 & 10 & 178 & 0.056
\end{tabular}

The Volumetric Flow Rate $\mathrm{Q}=\mathrm{VA}=203.37 \times 0.056=$ $10.17 \mathrm{~m}^{3} / \mathrm{s}$

Table 11: Measurement 6. Depth and Width Measurement

\begin{tabular}{llll}
\hline S/N & Distance & Depth & Area \\
\hline 1 & 3.1 & 1.12 & 1.74 \\
2 & 10 & 1.80 & 14.6 \\
3 & 10 & 2.56 & 21.8 \\
4 & 10 & 2.70 & 26.3 \\
5 & 10 & 3.40 & 30.5 \\
6 & 10 & 2.80 & 31.0 \\
7 & 10 & 1.65 & 27.3 \\
8 & 10 & 1.65 & 21.5 \\
9 & 10 & 1.51 & 7.55 \\
\hline Total Area & & & 182.29 \\
\hline
\end{tabular}

Table 12: Measurement 6. Velocity Measurement

\begin{tabular}{llll}
\hline S/N & Distance & Time & Velocity \\
\hline 1 & 10 & 180 & 0.056 \\
2 & 10 & 188 & 0.053 \\
3 & 10 & 180 & 0.056 \\
\hline Average Velocity & & 0.055 \\
\hline & \\
The Volumetric Flow Rate is $\mathrm{Q}=\mathrm{VA}=182.29 \times 0.055=$ \\
$10.03 \mathrm{~m}^{3} / \mathrm{s}$
\end{tabular}

Table 13: Measurement 7: Depth and Width Measurement

\begin{tabular}{llll}
\multicolumn{4}{c}{ Measurement } \\
\hline $\mathrm{S} / \mathrm{N}$ & Distance & Depth & Area \\
\hline 1 & 3.1 & 1.20 & 1.86 \\
2 & 10 & 1.90 & 15.5 \\
3 & 10 & 2.58 & 22.4 \\
4 & 10 & 2.61 & 25.95 \\
5 & 10 & 3.50 & 30.55 \\
6 & 10 & 2.98 & 32.4 \\
7 & 10 & 2.72 & 28.5 \\
8 & 10 & 1.70 & 22.1 \\
9 & 10 & 1.43 & 7.15 \\
\hline Total Area & & & 180.41 \\
\hline
\end{tabular}


Table 14: Measurement 7. Velocity Measurement

\begin{tabular}{llll}
\hline S/N & Distance & Time & Velocity \\
\hline 1 & 5 & 96 & 0.052 \\
2 & 5 & 100 & 0.05 \\
3 & 5 & 90 & 0.056 \\
\hline \multicolumn{7}{l}{ Average Velocity } \\
The Volumetric Flow Rate is $\mathrm{Q}=\mathrm{VA}=0.053 \times 186.41=$ \\
9.82 $\mathrm{m}^{3} / \mathrm{s}$
\end{tabular}

Table 15: Measurement 8. Depth and Width Measurement

\begin{tabular}{llll}
\hline S/N & Distance & Depth & Area \\
\hline 1 & 3.1 & 1.42 & 2.201 \\
2 & 10 & 1.91 & 16.65 \\
3 & 10 & 2.72 & 23.15 \\
4 & 10 & 2.68 & 27.0 \\
5 & 10 & 3.55 & 31.15 \\
6 & 10 & 3.21 & 33.8 \\
7 & 10 & 2.96 & 30.85 \\
8 & 10 & 2.40 & 26.80 \\
9 & 10 & 1.72 & 8.60 \\
\hline Total Area & & & 200.2 \\
\hline
\end{tabular}

\begin{tabular}{llll}
\multicolumn{4}{c}{ Table 19: Measurement 10. Depth and Width Measurement } \\
\hline S/N & Distance & Depth & Area \\
\hline 1 & 3.1 & 1.52 & 2.356 \\
2 & 10 & 1.84 & 10.80 \\
3 & 10 & 2.85 & 23.43 \\
4 & 10 & 2.90 & 28.75 \\
5 & 10 & 3.48 & 31.90 \\
6 & 10 & 3.20 & 33.40 \\
7 & 10 & 2.91 & 30.55 \\
8 & 10 & 2.32 & 26.15 \\
9 & 10 & 1.44 & 7.20 \\
\hline Total Area & & & 200.54 \\
\hline
\end{tabular}

Table 16: Measurement 8. Velocity Measurement

\begin{tabular}{llll}
\hline $\mathrm{S} / \mathrm{N}$ & Distance & Time & Velocity \\
\hline 1 & 10 & 170 & 0.059 \\
2 & 10 & 168 & 0.060 \\
3 & 10 & 176 & 0.051 \\
\hline Average Velocity & & 0.059 \\
\hline \multicolumn{7}{l}{ Thus, Volumetric Flow Rate is: $\mathrm{Q}=\mathrm{VA}=0.059 \times 200.2=$} \\
$11.75 \mathrm{~m}^{3} / \mathrm{s}$
\end{tabular}

Table 17: Measurement 9. Depth and Width

\begin{tabular}{llll}
\multicolumn{4}{c}{ Measurement } \\
\hline S/N & Distance & Depth & Area \\
\hline 1 & 3.1 & 1.26 & 1.95 \\
2 & 10 & 2.02 & 16.4 \\
3 & 10 & 2.61 & 23.7 \\
4 & 10 & 2.72 & 26.7 \\
5 & 10 & 3.50 & 31.1 \\
6 & 10 & 3.18 & 33.4 \\
7 & 10 & 2.83 & 30.05 \\
8 & 10 & 1.97 & 24.0 \\
9 & 10 & 1.56 & 24.0 \\
\hline Total Area & & & 187.3 \\
\hline
\end{tabular}

Table 18: Measurement 9. Velocity Measurement

\begin{tabular}{llll}
\hline S/N & Distance & Time $(s)$ & Velocity \\
\hline 1 & 10 & 190 & 0.053 \\
2 & 10 & 178 & 0.056 \\
3 & 10 & 182 & 0.055 \\
\hline
\end{tabular}

The Volumetric Flow Rate is $\mathrm{Q}=\mathrm{VA}=0.055 \times 187.3=$ $10.24 \mathrm{~m}^{3} / \mathrm{s}$

\begin{tabular}{llll}
\multicolumn{4}{c}{ Table 20: Measurement 10. Velocity Measurement } \\
\hline $\mathrm{S} / \mathrm{N}$ & Distance & Time & Velocity \\
\hline 1 & 10 & 162 & 0.062 \\
2 & 10 & 170 & 0.059 \\
3 & 10 & 176 & 0.057 \\
\hline \multicolumn{4}{l}{0.059} \\
\hline The Volumetric Flow Rate is $\mathrm{Q}=\mathrm{VA}=200 \times 0.059=11.90$ \\
$\mathrm{~m}^{3} / \mathrm{s}$ \\
The average fluid velocities and volumetric flow rates for \\
the ten different measurements are presented in Table \\
21.
\end{tabular}

Table 21: Float Method: Ave. Vel. and Vol. Flow Rate for 10 Measurements

\begin{tabular}{llll}
\hline Measurement & Fluid Vel. & Area & Flow Rate \\
\hline 1 & 0.073 & 186.37 & 13.6 \\
2 & 0.538 & 17.12 & 9.21 \\
3 & 1.8 & 24.30 & 43.0 \\
4 & 0.046 & 179.80 & 8.27 \\
5 & 0.056 & 203.37 & 10.17 \\
6 & 0.055 & 182.29 & 10.03 \\
7 & 0.053 & 186.41 & 9.82 \\
8 & 0.059 & 200.20 & 11.75 \\
9 & 0.055 & 187.3 & 10.24 \\
10 & 0.059 & 200.54 & 11.90 \\
\hline Average & 0.2794 & 156.77 & 13.8 \\
\hline
\end{tabular}

From the Table 21, the average volumetric flow rate of River Ethiope using the Float Method is $13.8 \mathrm{~m}^{3} / \mathrm{s}$.

\subsubsection{Current Meter Method}

An alternative method to measure flow rate is the Bridge Broom or Current Meter Method. The measurement was carried out from the bridge across the River Ethiope at Abraka/Benin Express Road, Abraka. In this method, the river cross-section is divided in partial areas (subsections) for which the hydraulic area and an average velocity are determined [10].

The total discharge is the summation of the products of area and mean velocity for all subsections. Width was determined from a graduated tape stretched across the measured section.

The results of the current meter measurements were manually recorded and presented in Table 22 . 
Table 22 Results of Current Meter Measurement. DISCHARGE MEASUREMENT NOTES

RIVER: ETHIOPE RIVER

DATE:

LOCATION: ABRAKA

\begin{tabular}{|c|c|c|c|c|c|c|c|c|c|c|}
\hline \multirow{2}{*}{$\begin{array}{l}\text { Dist } \\
\text { initial } \\
\text { (m) }\end{array}$} & \multirow{2}{*}{$\begin{array}{l}\text { from } \\
\text { point }\end{array}$} & \multirow{2}{*}{$\begin{array}{l}\text { Depth } \\
\text { (m) }\end{array}$} & \multirow{2}{*}{$\begin{array}{l}\text { Depth of observed } \\
\text { (h) }\end{array}$} & \multirow{2}{*}{$\begin{array}{l}\text { No. of } \\
\text { Revs. }\end{array}$} & \multirow{2}{*}{$\begin{array}{l}\text { Time } \\
\text { (secs) }\end{array}$} & \multirow{2}{*}{$\begin{array}{l}\mathrm{Re} / \mathrm{sec} \\
\mathrm{N}\end{array}$} & \multicolumn{2}{|c|}{ Velocity $(\mathrm{m} / \mathrm{s})$} & \multirow{2}{*}{$\begin{array}{l}\text { Area } \\
\left(\mathrm{m}^{2}\right)\end{array}$} & \multirow{2}{*}{$\begin{array}{l}\text { Discharge } \\
\left(\mathrm{m}^{3} / \mathrm{s}\right)\end{array}$} \\
\hline & & & & & & & $\begin{array}{l}\text { At } \\
\text { point }\end{array}$ & $\begin{array}{l}\text { Mean in } \\
\text { Vertical }\end{array}$ & & \\
\hline 0 & & --- & ----- & ----- & & & & & & \\
\hline 6 & & 1.05 & 0.63 & 20 & 10 & 2.0 & & 0.244 & 3.15 & 0.7686 \\
\hline 8 & & 0.95 & 0.57 & 34 & 10 & 3.4 & & 0.399 & 3.80 & 1.5162 \\
\hline \multirow[t]{2}{*}{10} & & 1.35 & 0.27 & 45 & 10 & 4.5 & 0.520 & 0.498 & 2.7 & 1.3446 \\
\hline & & & 1.08 & 41 & 10 & 4.1 & 0.476 & & & \\
\hline \multirow[t]{2}{*}{12} & & 1.45 & 0.29 & 58 & 10 & 5.8 & 0.660 & 0.579 & 2.9 & 1.6791 \\
\hline & & & 1.16 & 43 & 10 & 4.3 & 0.498 & & & \\
\hline \multirow[t]{2}{*}{14} & & 1.85 & 0.37 & 58 & 10 & 5.8 & 0.660 & 0.623 & 3.7 & 2.3051 \\
\hline & & & 1.48 & 51 & 10 & 5.1 & 0.585 & & & \\
\hline \multirow[t]{2}{*}{16} & & 2.15 & 0.43 & 71 & 10 & 7.1 & 0.799 & 0.783 & 4.3 & 3.3669 \\
\hline & & & 1.72 & 68 & 10 & 6.8 & 0.767 & & & \\
\hline \multirow[t]{2}{*}{18} & & 2.15 & 0.43 & 58 & 10 & 5.8 & 0.660 & 0.778 & 4.3 & 3.3454 \\
\hline & & & 1.72 & 80 & 10 & 8.0 & 0.896 & & & \\
\hline \multirow[t]{2}{*}{20} & & 2.15 & 0.43 & 84 & 10 & 8.4 & 0.939 & 0.928 & 4.3 & 3.9904 \\
\hline & & & 1.72 & 82 & 10 & 8.2 & 0.917 & & & \\
\hline \multirow[t]{2}{*}{22} & & 2.75 & 0.55 & 80 & 10 & 8.0 & 0.896 & 0.725 & 5.5 & 3.9815 \\
\hline & & & 2.22 & 48 & 10 & 4.8 & 0.553 & & & \\
\hline \multirow[t]{2}{*}{24} & & 2.55 & 0.51 & 64 & 10 & 6.4 & 0.724 & 0.703 & 5.1 & 3.5853 \\
\hline & & & 2.04 & 60 & 10 & 6.0 & 0.682 & & & \\
\hline \multirow[t]{2}{*}{26} & & 2.15 & 0.43 & 54 & 10 & 5.4 & 0.617 & 0.628 & 4.3 & 2.7004 \\
\hline & & & 1.72 & 56 & 10 & 5.6 & 0.639 & & & \\
\hline \multirow[t]{2}{*}{28} & & 1.6 & 0.32 & 46 & 10 & 4.6 & 0.531 & 0.471 & 3.2 & 1.5056 \\
\hline & & & 1.28 & 35 & 10 & 3.5 & 0.410 & & & \\
\hline \multirow[t]{2}{*}{30} & & 1.25 & 0.25 & ---- & ---- & ---- & & & & \\
\hline & & & 1.00 & 37 & 10 & 3.7 & & 0.432 & 3.5 & 1.08 \\
\hline 32 & & 1.05 & 0.63 & 22 & 10 & 2.2 & & 0.266 & 2.1 & 0.5586 \\
\hline \multirow[t]{2}{*}{35} & & & ----- & & & & & & & \\
\hline & & & & & 10 & & & & & \\
\hline
\end{tabular}

Total discharge from the current meter measurement, $\mathrm{Q}=31.7337 \mathrm{~m}^{3} / \mathrm{s}$

For the measurement of the flow in this study, the SKT model was used.

The total river discharge is;

$$
\begin{aligned}
& \mathrm{Q}=\mathrm{a}_{1} \mathrm{~V}_{\mathrm{n}}+\mathrm{a}_{2} \mathrm{~V}_{\mathrm{n}}+\mathrm{a}_{3} \mathrm{~V}_{\mathrm{n}}+\ldots \ldots \ldots+\mathrm{a}_{\mathrm{n}} \mathrm{V}_{\mathrm{n}} \\
& \mathrm{Q}=\mathrm{q}_{1}+\mathrm{q}_{2}+\mathrm{q}_{3}+\ldots \ldots \ldots \ldots \ldots+\mathrm{q}_{\mathrm{n}}
\end{aligned}
$$

To obtain the first discharge ' $q$ ' from Figure 9 which represent a triangle or a partial area, I used;

The revolution per second is calculated from the Data obtained during measurement is Rev/Sec,

$$
n=\frac{\text { No of revolutions }}{\text { Time taken }}
$$

The equivalent of $\mathrm{n}$ can be obtained from the calibration chart for the Valeport BFM002 miniature current meter.

The first readings from Table 3.22, Rev/Sec $=2$

The equivalent of $2 \mathrm{rev} / \mathrm{sec}$ from the BFM002 chart is $\mathrm{V}_{\mathrm{n}}=0.244 \mathrm{~m} / \mathrm{s}$

The area $=1 / 2 \times b \times h=1 / 2 \times 6 \times 1.05=3.15 \mathrm{~m}^{2}$
The discharge $\mathrm{Q}_{1}=$ Velocity $\times$ Area $=\mathrm{V}_{\mathrm{n}} \times \mathrm{A}=0.244$ $\times 3.15=0.7686 \mathrm{~m}^{3} / \mathrm{s}$

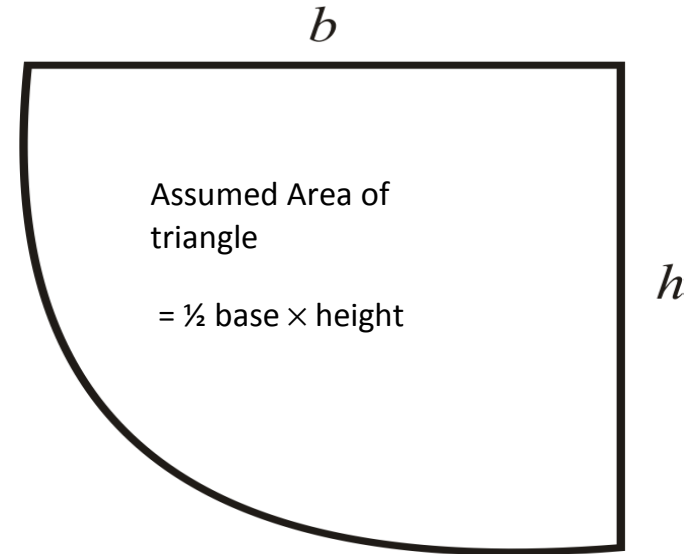

Figure 8: Illustration of the first portion to be calculated.

The second discharge is obtained following same procedure.

Subsequent measurements from one end of the river bank to the other end will be assumed to be a 
rectangle whose area is Length $\times$ Breadth. The length is the depth while the width is the breadth.

i.e. $\mathrm{L} \times \mathrm{B}=1.35 \times 2.0=2.7 \mathrm{~m}^{3}$

The discharge $\mathrm{q}_{3}=$ Velocity $\times$ Area $=\mathrm{V}_{\mathrm{n}} \times \mathrm{A}=0.498$ $\times 2.7=1.3446 \mathrm{~m}^{3} / \mathrm{s}$

The other sectional discharge can be obtained at various measured interval spanning the whole width of the river. From the Table 22, the total volumetric flow rate of Ethiope River using the current meter method is $Q=31.73 \mathrm{~m}^{3} / \mathrm{s}$.

\subsection{Discussion}

The discrepancies between the data obtained by the Float Method and the Current Meter Method can mainly be attributed to the inaccuracies in performing the float method at the Ethiope River. Measuring depth of the river from a boat may be inaccurate since the same spot could not be obtained all the time as a result of not able to keep the boat from shifting. Since sand miners are always mining sand at the lake, and sometimes deposition of material in the river bed could cause unstable cross-sections which will ultimately affect the discharge.

Also, the float velocity may have been affected by wind since most measurements were carried out in the evening where wind velocities are high. Besides, the presence of aquatic growth and the collapsed bridge at the lake may have affected the velocity measurement using the float method. Thus the data obtained from the current meter method will be the primary data used to characterize and evaluate the water source of Ethiope River at the lake at Umutu.

\subsubsection{Estimating the Hydropower Potential of the Ethiope River}

Concisely and within hydrological context, it involves the determination of the technologically feasible limits of the gross hydropower potential (GHP) of the studied river basin. By definition, GHP is the theoretical optimum limits of hydropower generation (HPG) of any river basin which represents the potential that possible feasible fall and flow within the basin constitutes.

Conceptually, GHP is proportional to the product of gross head and discharge which can be determined from equation (13) [11]

$$
\mathrm{P}=\eta \rho g Q H
$$

In (13), $P$ is Power (watts), $\eta$ is overall efficiency (\%), $\rho$ is the density of water $\left(1000 \mathrm{~kg} / \mathrm{m}^{3}\right), \mathrm{g}$ is the acceleration due to gravity $\left(9.81 \mathrm{~m} / \mathrm{s}^{2}\right), \mathrm{Q}$ is the water discharge $\left(\mathrm{m}^{3} / \mathrm{s}\right)$ and $\mathrm{H}$ is the gross head $(\mathrm{m})$.

The result of the discharge $\left(31.73 \mathrm{~m}^{3} / \mathrm{s}\right)$ obtained from the Current meter method was used for its high degree of accuracy. From the depth measurement, a head of $5 \mathrm{~m}$ and efficiency of 0.85 was estimated for evaluating the power potential of the Ethiope River. That is:

$\mathrm{P}=0.85 \times 1000 \times 9.81 \times 31.73 \times 5=1.323 \mathrm{MW}$.

The available potential power from the Ethiope River at a flow of $31.73 \mathrm{~m}^{3} / \mathrm{s}$ and a gross head of $5 \mathrm{~m}$ if completely dedicated as off-grid supply can meet the electric energy requirements of the surrounding communities. 1.323 MW of electricity on a steady basis can do a lot to change the standard of living of the surrounding communities and generate revenue for the owners of the scheme.

\section{CONCLUSIONS}

The purpose of the study was to determine the flow rate of the Ethiope River using the float and current meter methods. The results were compared and the result of the current meter method with high degree of accuracy was used to estimate the power potential of the River. Also the result show the availability of huge reserves of easily exploitable water, much of it flowing to waste that could be used to develop the agricultural and electricity generation potential of Delta State. The result would find application in flood management, water supply and appropriate designs of bridges and culverts. Finally, while flow characteristics have been determined from this study using the float and current meter methods, it is important that the existing gauge at Abraka be replaced and maintained at regular interval so that accurate discharge data collection can resume.

\section{REFERENCES}

[1]. Omo-Irabor, 0.0 and Olobaniyi, S.B (2007). Investigation of the Hydrological Quality of Ethiope River Watershed, Southern Nigeria.Journal of Applied Science and Environmental Management.Vol.11 (2) 13-19.

[2]. Ikomi, R. B (1996). The Biology of the African leaf fish Polycentropsis abbreviate (Boulenger 1905) in River Ethiope, Nigeria. ActaIcthyologicaet PISC (XXVI), 1-14.

[3]. Adiotomre, E.A; Adaikpoh, E.O and Erhisere, O (1999).The gravel packing properties of Sand Deposit in the Ethiope River Catchment. Geo Research 4 2126.

Vol. 34, No. 1, January 2015 
[4] Akpoborie, I.A (2012). Time Series Analysis of streamflow variability in the Ethiope and Adofi Rivers, Delta State, Nigeria, In: Akpotor, A.S et al.(Eds.) Five Decades of Oil Production in Nigeria: Impact on the Niger Delta. CENDS, Abraka, pp 275290.

[5] Osula, A.A (2007).Investigations and Assessment of Small Hydropower (SHP) potentials in some rivers within Benin-Owena River Basin Development Area. Water Resources 17: 29-38.

[6]. Antigha R.E.E, Akor A.J, Ayotamuno M.J, Ologhodien I and Ogarekpe N.M (2014). Rainfall Run-off Model for Calabar Metropolis Using Multiple Regression. Nigerian Journal of Technology (NIJOTECH). Vol.33 No 4 pp 566-573.

[7]. Arora K. R (2009). Irrigation, Water Power and Water Resources Engineering.Publisher - Jain A.K for Standard Publishers Distributions, 1705-B, NAI SARAK, Delhi.
[8]. Dogara B (2004). Hydrological Studies for Small Hygrdopower Planning - Guide Book on SHP Development in Nigeria. Energy Commission of Nigeria.

[9]. Kuusisto E (1996). Hydrological measurements, water quality monitoring - A Practical Guide to the Design and implementation of Fresh water Quality Studies and Monitoring Programme, published on behalf of United Nations Environmental Programme and the World Health Organisation, UNEP/WHO ISBN 0419223207 (Hbk)0419213304 (Pbk).

[10]. Soenksen, P.J, Brandi, B.F, Jason, S.A and Schaepe, N.J (2010). Streamflow Gains and Losses in the Niobrara River Basin, Nebraska, 1980 and 2009.Journal of Environmental Hydrology.Vol 18, paper 11 .

[11]. Sule, B.F, Salami, A.W, Bilewu, S.O, Adeleke, 0.0 and Ajimotokan, H.A (2011). Hydrology of River Oyun and Hydropower Potential of Unilorin Dam, Ilorin, Kwara State, Nigeria. New York Science Journal, 4 (1) 69-78 